\title{
Transparency and accountability in the Nepalese corporate sector: a critical assessment
}

\section{Authors}

Saramsh Kharel: Aspiring professional in social entrepreneurship promotion and business process outsourcing. saramskhrl99@gmail.com

Sabina Magar: An aspiring specialist for integrated business management.

Nitu Chaurasiya: Aspiring professional in management academia and responsible institutional management for sustainability.

Sumi Maharjan: an emerging youth icon in social entrepreneurship.

Chandra Prasad Rijal: Senior management consultant

\section{Key Words}

Accountability, corruption, empowerment, good governance, transparency, and sustainable development.

\begin{abstract}
Background: In the present changing context of Nepal, accountability and transparency may not only be treated as functionally interdependent, but also equally important in the process of maintaining effective governance in all contexts by imparting a system based on fairness, ethics, accountability, transparency and delivered quality. Therefore, it is essential for organizations to follow the pathways of sustainable governance in order to enhance their desired level system efficiency and effectiveness.
\end{abstract}

Objectives: Primarily, the present work was accomplished to have a critical assessment of prevalence of corporate governance in the Nepalese corporate sector with focus on compliance of transparency and accountability.

Methods: The present work was accomplished using a fully qualitative method of inquiry by performing a compliance review of transparency and accountability.

Results: Universal evidence of existing literature confirms that accountability and transparency play vital role in transforming organizational trustworthiness. The practice of transparency provides access to convenient and reliable information required to enhance organizational decision-making, which ultimately results in improved level of performance. As a component ethical management, corporate governance, refers to the visionary proposition of organizational leadership for shared expectations of valued stakeholders. The world practices confirm that both transparency and accountability should go side by side to achieve quality and ethical organizational system practices, results and outcomes.

Conclusions: Since Nepal is a new practitioner of modern concepts of corporate governance, its effective compliance is still infant. Thus, the Government of Nepal needs to devise and enact needful policy reforms.

Implications: The present paper may serve instrumental as it attempts to analyze the existing evidences, discusses how approaches to learning of transparency and accountability might be improved, and recommends how the Nepalese corporate sector in the field of $C G$ could be enhanced and empowered with a vision to sustainable corporate development and promotion in the country.

Paper type: Review paper

For citation and referencing of this article:

Kharel, S., Magar, S., Chaurasiya, N., Maharjan, S. \& Rijal, C.P. (2019). Functional transparency and accountability in the Nepalese corporate sector: A critical assessment. Quest Journal of Management and Social Sciences: Corporate Governance Edition, 1(1), 1-25. Kathmandu: Quest Scientific Publications. 


\section{Introduction}

Transparency and accountability initiatives (TAIs) have taken democratization, governance, aid and development circles by storm since the turn of the many actors involved with them regarding various donors, funders, program managers, implementers and researchers are now keen to know more about what these initiatives are achieving. Different pressures and interests like market pressures, external discourse and internal norms lie behind different actors' curiosity but the consensus is clear and stated that it is high time that impacts and effectiveness of TAI are understood well (Gaventa \& McGee, 2013; \& Hale, 2008).

Over the last decade, a vast amount of academic as well as policy-support research has been conducted on integrity, transparency and accountability and conversely corruption in the public sector. The issue of ethical conduct in the public sector and its employees received a great deal of focus from international, regional, transnational, and national organizations, interested in promoting the performance of the public sector (Hale, 2008). A consensus has developed world-wide over the importance of reforming corporate sector to strengthen integrity, transparency and accountability and to prevent and combat corruption. Such reforms are crucial in protecting public resources, enhancing public sector performance, and strengthening the government's role in orchestrating development and providing basic services, along with empowering the Nepalese corporate sectors as a whole (Ashour, 2004). However, these are very old themes of compliance in the developed world, transparency and accountability (T\&A) have emerged as crucial issues in the Nepalese context over the past decade to address both developmental failures and democratic deficits (Gaventa \& McGee, 2013). In the development and aid context, the argument is that through greater accountability, the leaky pipes of corruption and inefficiency will be repaired, aid and public spending will be channeled more effectively and development initiatives will produce greater and more visible results.

Since, corporate governance (CG) reforms are of great significance for developing countries like Nepal, to gain a sustained effort. In this difficult situation of Nepalese corporate sector the practice of good governance with transparency and accountability towards their customers and employees is very much important. In this paper we explored the themes of accountability and transparency as an ideal configuration for Nepalese corporate sectors.

The primary purpose of the present work was to have a critical assessment of the prevalence of corporate governance in the Nepalese corporate sector with focus on compliance of transparency and accountability. To accomplish this purpose more specifically, the present work aimed to -

a. analyze the issues and challenges facing the implementation of transparency and accountability in the Nepalese corporate sector,

b. examine the effect of compliance of transparency and accountability in context of Nepalese corporate sector,

c. identify and examine the prevailing global best practices in respect with compliance of transparency and accountability in the corporate sector, and

d. produce relevant strategic implications for effective compliance of expected functional transparency and accountability in the Nepalese corporate sector with an aim to transform its sustainable development. 
In the past, so many organizations in Nepal have been involved in unethical practices, which puts the credibility of their corporate image doubt. One of them is private sector business. The private sector business is often accused of smuggling, black-marketing, and adulteration, selling fake products, collusion, cartelling and outright bribery. We have now health, education and transport mafias. Our finance and cooperative sector is riddled with thugs and swindlers (Manandhar, 2016).

Likewise, according to Himalayan times FNCCI an apex body of the private sector business dragged into controversy when a more than three decades old corruption case related to its president got reopened. Similarly, the directors of the Unity Life Insurance who swindled, from 400,000 members, billions of rupees through their Ponzi-like scheme. In the past, we have seen how a booming private sector carpet industry collapsed after being charged with unethical practices like the use of child labor, infringement of labor rights and environmental concerns. Nepalese private sector business is constantly facing ethical dilemmas. Most management of such outfits were not accountable to stakeholders of the companies. Besides, the counts and the regulatory agencies were short of authority, corruption and kickbacks were part of the system in the companies. The poor governance practices led to the collapse of so many companies in Nepal.

In this difficult situation of Nepalese corporate sector the practice of effective governance with transparency and accountability towards their customers and employees is very much important. In this paper we explored the themes of accountability and transparency as an ideal configuration for Nepalese corporate sectors. It also provides explanations on why and how accountability and transparency has empowered corporate sectors in Nepal.

More recently, there are many studies carried out globally in the field of corporate governance with focus on transparency and accountability. Many studies have attempted to establish empirical relationship between the private and public sector, however the results of such studies differed with each other. The present study focused on exploration of the level of compliance in terms of maintaining transparency and accountability as the two key pillars of managing corporate governance situation in the developing context of Nepal. For this, the present work was guided by a set of pre-defined research questions stated as follows --

a. How is the overall scenario of corporate governance in the Nepalese corporate sector?

b. How is the present situation of empowerment in the Nepalese corporate sector from the perspective of maintaining transparency and accountability?

c. What are the effects of maintaining transparency and accountability as the key instruments of corporate governance?

d. What are the issues and challenges facing the process of maintaining transparency and accountability in the Nepalese corporate sector?

e. What corrective measure should the initiated to promote the compliance of transparency and accountability in the Nepalese corporate sector?

For the simplicity of its readers, the study team established a set of operational definitions of the key terms related to the central idea of the present study. 
Transparency: According to Armstrong (2005), the concept of transparency serves as a mandatory system that provides advocacy on providing access to public for convenient and reliable information pertaining to performance and decision-making in the public sector organizations. For the purpose of this paper, the term 'transparency' refers to the state of institutional openness to provide public access to optimum level of information about the company, its strategic decisions and regular operations. Reich (2018), Figueiras (2016) and Fox (2007) have observed transparency as an institutional policy morale since it allows learning, influencing and maximizing accountability with a shared aim to shape the organizational performance. Thus, transparency serves as an ethical business process with a universal understanding that substantive and procedural information is available to the stakeholders which may offer more advantages to the involved stakeholders (Johnston, n. d.; Filho et al., 2016).

Accountability: The principle of accountability refers to the clear statement of governance rules and responsibilities and the protection of the company management and shareholder interests by the board of directors. In other words, accountability refers to the disclosure of governance roles and responsibilities, the provision of voluntary support for ensuring the compliance of its shareholders and managers and continuously monitoring them by the board of directors with objective and meaningful jurisdiction.

It is understood that accountability refers to the practice of governance principles and rigorously monitoring its implementation. The researchers have specified the term accountability in numerous ways and they tend to agree in common that accountability reserves the right to receive information and obligation to release details for expansion of transparency, which allows reduction of information asymmetry between principal and agent thereby achieving goals of public interest. Thus, accountability refers to the procedures that require officials to follow established rules defining the standards and demonstration of equal participation regarding the practice of those defined standards (Reich, 2018; Figueiras, 2016; Fox, 2007).

The two terms, transparency and accountability, are often used interchangeably (Bovens, 2007) as the modern missions are summed up as the means of strengthening democracy and development through rigorous empowering of citizens to hold their governing institutions to account. Thus, transparency and accountability in corporate governance refers to the effective dissemination of information and continuous practice of ethical governance responsibilities.

Accomplished in the spring season of 2019, this paper is the outcome of two consecutive articleship projects as an academic course requirement on corporate governance in Master of Business Administration (MBA) degree offered at Quest International College, an affiliate institution of Pokhara University. The overall work was accomplished using a fully qualitative method of study by performing depth review of various principles and practices related to the compliance of transparency and accountability in the corporate sector.

Keeping in view the objective of the study and nature of research questions taken into consideration, adequate effort was vested on exploration and critical analyses of information collected from diverse sources, mostly using desk research method. Thus, all the findings of this work are based on secondary sources. Information has been collected and shifted from the documents such as the books, journals, official declarations, group discussions, seminar sessions, newspaper articles and expert facilitation. 
This paper aims to produce effective inputs supporting the Nepalese corporate sector through effective governance practices in maintaining transparency and accountability under changing context of the country. The overall scope of the work was confined to explore the principles and practices of corporate governance, followed by diagnoses of major issues, challenges and ways forward to transform the Nepalese corporate sector as per the need and urgency of the time. Precisely, this paper deals with strategic course of action required to empower Nepalese corporate sector by effective compliance of transparency and accountability requirements under changing situation.

\section{Review of literature}

For the purpose of accomplishing the present work in a scientifically grounded manner, the present study team has performed needs-based review of literature from at least four perspectives - theoretical or conceptual reviews, empirical discussions, exploration of research gaps, and development of conceptual framework governing the present study.

\section{Conceptual perspectives of corporate governance}

Various scholars have referred the term governance in different ways. For instance, Adhikari (2014) and Gisselquist (2012) have claimed governance as a process or act of governing an institution or any other macro system. According to these scholars, when it comes to an organized corporate sector, it is the way by which an organization is directed or controlled. The relative effectiveness of corporate governance has a profound effect on how well a business performs. General observation shows that businesses have prospered and remained prosperous are those that have found ways to govern their affairs effectively. Corporate governance improvements are of great importance for developing countries like Nepal, to gain a continued effort to attract FDI and Foreign Portfolio Management, and to organize greater savings through capital market (Sapkota, 2008).

Claessens and Fan (2002) has examined three critical measures for agency problems; low corporate transparency, extensive group structures and diversification, and risky financial structures and in case of Nepal, adverse political situations, past conflicts have hindered the implications of corporate governance (Magar et al., 2015) thus, rising fundamental tensions between director and shareholders as depicted by (Berle \& Gardiner, 1932). Sapkota et al. (2015) have stated that board of directors are important for the practice of corporate governance in any firms and considering the vitality of independent director on board, NRB has made it mandatory regarding the appointment of an independent director.

Sigdel and Koirala (2015) have examined that the banking and financial system fundamentally intervenes in capital formation in an economy; accepting deposits through customers, raising capital from investors (supply-side of credit) and mobilize to lend this money for business ventures and other economic activities (demand side) to purchase securities and provide other various types of financial services to customers.

Organization for Economic Co-operation and Development ([OECD], 1999) has defined corporate governance as a set of relationships between a company's management, board, 
shareholders and other stakeholders. It also provides the structure through which objectives of the company are set, and the means of attaining those objectives and monitoring performance. For illustration, NRB facilitates the additional control measures for capital fund, especially the tier second (supplementary) capital (NRB Report, 2013).

According to OECD (2015), corporate governance involves a set of relationships between a comapnys management, its board, its shareholders and other stakeholders. There are six principle of corporate governance. The revised Principles maintain many of the recommendations from earlier versions as continuing essential components of an effective corporate governance framework. They have introduce some new issues and provide greater emphasis or additional clarity to others.

The revised six principles include:

a. Ensuring the basis for an effective corporate governance framework: The corporate governance framework should promote transparent and fair markets, and the efficient allocation of resources. It focuses on the quality and consistency the different elements of regulations that influence corporate governance practices and the division of responsibilities between authorities. In particular, new emphasis is placed on the quality of supervision and enforcement. The chapter also includes a new principle on the role of stock markets in supporting good corporate governance.

b. The rights and equitable treatment of shareholders and key ownership functions: Organizations should respect the rights of shareholders and help shareholders to exercise those rights. They can help shareholders exercise their rights by effectively communicating information that is understandable and accessible and encouraging shareholders to participate in general meetings.

c. The equitable treatment of shareholders: The corporate governance framework should ensure the equitable treatment of all shareholders, including minority and foreign shareholders. It further ensures that shareholders should have the opportunity to obtain effective redress for violation of their rights. For example; minority shareholders should be protected from abusive actions by, or in the interest of, controlling shareholders acting either directly or indirectly, and should have effective means of redress. The principle also highlights the need to disclose and minimize conflicts of interest that may compromise the integrity of proxy advisors, analysts, brokers, rating agencies and others that provide analysis and advice that is relevant to investors. It also contains new principles with respect to cross border listings and the importance of fair and effective price discovery in stock markets.

d. The role of stakeholders in corporate governance: The Principles encourage active co-operation between corporations and stakeholders and underline the importance of recognizing the rights of stakeholders established by law or through mutual agreements. It should recognize the rights of stakeholders established by law or through mutual agreements and encourage active cooperation between corporations and stakeholders in creating wealth, jobs, and sustainability of financially sound enter- 
prise. The chapter also supports stakeholders' access to information on a timely and regular basis and their rights to obtain redress for violations of their rights.

e. Disclosure and transparency: Organizations should clarify and make publicly known the roles and responsibilities of board and management to provide shareholders with a level of accountability. It should ensure that disclosure needs to be made on all material matters regarding the cooperation, including the financial situation, performance, ownership, and governance of the company both timely and accurately. Disclosure of material matters concerning the organization should be timely and balanced to ensure that all investors have access to clear, factual information. For example; an annual audit should be conducted by an independent, competent and qualified, auditor in order to provide an external and objective assurance to the board and shareholders that the financial statements fairly represent the financial position and performance of the company in all the material aspects and monetary transaction.

$f$. The responsibilities of the board: The OECD guidelines provide a great deal of details about the functions of the board in protecting the company and its shareholders. These include concerns about corporate strategy, risk, executive compensation and performance as well as accounting and reporting system. For example; the board should apply high ethical standards and should account the interest of stakeholders.

Thus, these are the various principles of corporate governance that actually regulates and governs the corporate sectors locally and globally. These frameworks can be used by the policymakers by systematically examining and developing the legal and regulatory frameworks for corporate governance which will reflect their capability regarding the dimensions of external environment, to develop their own practice.

\section{Principles and practices of transparency and accountability}

Nepalese banks are operated via Banks and Financial Institution Act (BAFIA) 2006, companies act 2006, and regulated under the supervision of Nepal Rastra Bank (Adhikari, 2014). Commercial banks are mandate to make the deposits and capital fund transparent. For instance, commercial Bank occupies 78.2 percent of total assets, 81.2 percent of total deposits, and total capital fund of NRs. 94,661 million (NRB Report, 2013).

The term 'governance' has been defined differently by different scholars in different contexts and situations. According to European Union (as cited in Khodary, 2016), governance is a rules, process and behavior which affect the way of performance at different level particularly as regard to openness, participation, accountability, effectiveness and coherence effectiveness and coherence. A scholar has revisited that most of the people take the words 'government' and 'governance' as a same way but these are two different dimensions. Government may be defined as the predominant part of the institutional environment, it is only one piece of the puzzle of regional governance as carried out by a broader range of regional 
institution (Wolman, Levy \& Hincapie, 2008). To clarify, government is a territorially based body that makes authoritative decisions, for which it has constitutional or legislative authority, that are binding on residents and businesses within its boundaries, whereas governance is the process through which various stakeholders articulate their interest, exercise their right, and mediate their differences (Avellaneda, 2006).

Other scholars have contradicted this view. According to these scholars, effective governance is essential for both private and public sectors to make decisions of governing, especially among the state and non-stat actors that acquire and exercises the authority including in setting the rules of engagement and the policies for making the society and its institutions work (Levy, Brown, \& Jong, 2010). It implies that governance is about defining rules, regulation, institutional mechanisms and structures for delivery of goods, and processes by which such structures and mechanisms operate. It focuses on articulation of interests by various stakeholders, specially the previously excluded and the marginalized.

On the other hand, corporate governance (CG) consists of a set of internal procedures, laws, and informal guidelines that govern how corporate officials make decisions protecting the interests of the shareholders from agency problems and managers personal benefit regarding the poor governance mechanism and those who bear responsibility for harms, losses, or injuries that flow from such decisions (Iksander, \& Chamlou, 2000; Monks, \& Minow, 2004; \& Thomsen, 2008; as cited in Adhikari, 2014; Ghimire et al., 2015). This scholar has defined corporate governance is a system of leadership and control of the company which ensures to establish the strategies, protect right to get relevant information, interact and communicate with the management and equitable treatment of all shareholders.

From the above literatures corporate governance refers to the management and control of the company. The corporate governance mechanism tries to reduce or eliminate the problems between the principal-agent. The principal delegates the decisive rights to the manager to act in the mechanism is implemented to assist in aligning the functions of managers with shareholders. The Board plays important role in corporate governance mechanism. Thus, according to (Wolfensohn, 1999) has defined corporate governance as about promoting corporate fairness, transparency and accountability.

Chauhan (2015) has provided examples regarding the failures of huge companies like Xerox, WorldCom, Enron, Global Crossing, Tyco and others collapse just because of neglecting the benefits of all the stakeholders. In the same context, Classens and Fan (2002) have depicted that even when the audit firms toughened their standards, those firms which provided high quality monitoring services lost market share to low-quality audit firms because of the weak government enforcement of accounting standards thus, weakening the effectiveness of retaining quality auditors, an important input for corporate governance mechanism.

Since emerging markets continues to grow in developing economies, and becomes more integrated with the global economy, more research work is required to study and review this area and therefor it is important to make corporate governance established and matured, as examined by (Sen \& Garani, 2015). 
The stakeholders have stressed the need for implementing the practice of corporate governance at professional level and is a challenging task in Nepalese corporation. In this respect, various executives have shared their thoughts regarding the practice of corporate governance as observed in (Himalayan News Service, 2018) where NEA managing director, Kulman Ghising said corporate governance is not only about taking responsibility but also about being ethical accountable and transparent and the most important thing is building a team by utilizing the strengths of each employee. Similarly, director of Jyoti Group, Saurabh Jyoti stated that corporate governance is equallwy important even in a family-owned business since right output by an employee in the right place helps in achieving organization goals and vision. On the same contrary, the CEO of Mega bank said that individual personality, attitude and aptitude enhances the performance that will consequently lead to competent governance as this is important for emerging economies since it encourages foreign direct investment.

\section{Conceptual frameworks of corporate governance}

In the corporate governance there are different authors described different model differently but Prasad (as cited in Kalika, 2018) has stated two models from the point of view of beneficiary- (i) liberal and (ii) coordinated. The liberal model of the Corporate Governance gives emphasis to the interest of the shareholders. It is found in the Anglo-American countries that prefer capitalism model of economy. The coordinated model of Corporate Governance recognizes the larger interest of the workers, managers, suppliers, customers and the general community. However, the both have distinct competitive advantage performed in the different ways. Nepalese legislations such as, Company Act, Bank and Financial Institution Act of 2063 and, Nepal Rastra Bank Act are influenced by the liberal model of corporate governance.

The anglo-American model: This is also known as unitary Board model, in which all Directors participate in a single Board comprising both executive and non-executive Directors in varying proportions. This model is also called Anglo-Saxon model because it is in practice in America, Britain, Canada, Australia, and other Commonwealth law countries including India. This model can be clearer with the help of a figure presented below:

Figure 1: Anglo American model of corporate governance

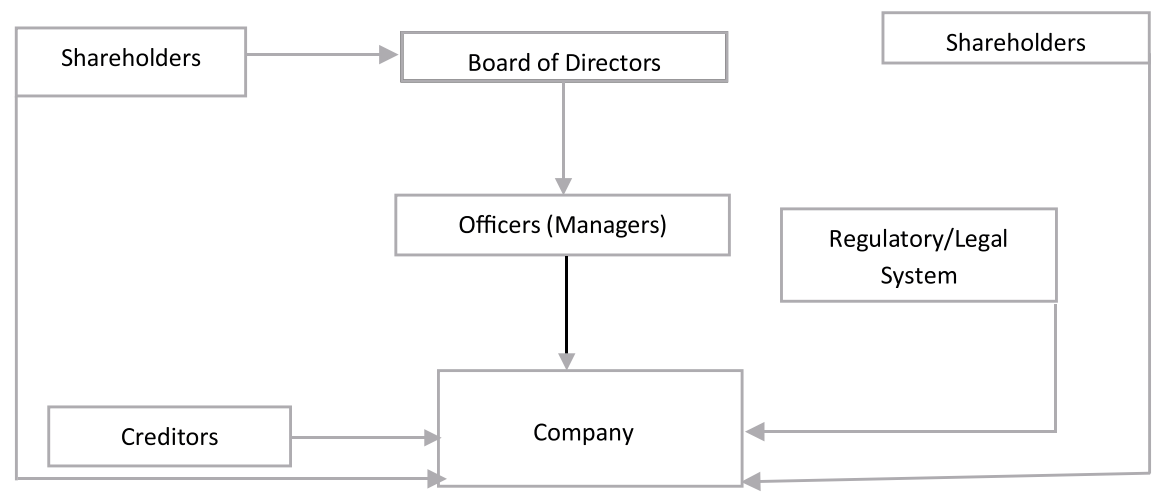

Source: Upadhyaya, T. P. (2013). Corporate governance practices in commercial banks of Nepal. 
This is shareholders oriented model and the some features of this model are as follows:

a. Division of ownership is likely to be divided equally between individual shareholders and institutional shareholders.

b. Directors are rarely independent of management.

c. There is fairly separation of ownership and management function.

d. Institutional investors are reluctant of what management doing.

The disclosure norms are high and comprehensive, the rules against insider trading are tight, and the penalty for price manipulation stiff.

Corporate governance model in Nepal: There is a legal provision to maintaining good governance in the corporate sectors of Nepal which are mentioned in Good Governance (Management and Operation) Act, 2064. The main objectives of this act is to making public administration of the country pro-people, accountable, transparent, inclusive and participatory and make available its outcome to the general public by creating corruption-free and smart (lean or smooth) administration, financial discipline, and efficient management of public work.

On the other hand Nepal Rastra Bank also has the provisions of Good Governance concerned to Banking and Financial institutions in Nepal. Company Act, Security Act, BAFIA, are some major sources of governance along with regulatory bodies. The model presented over here is based on the above Act as well as the role played by prevailing active regulatory bodies of Nepal (Upadhyaya, 2013). This model can be clearer with the help of a figure given below:

Figure 2: Corporate governance model for Nepal

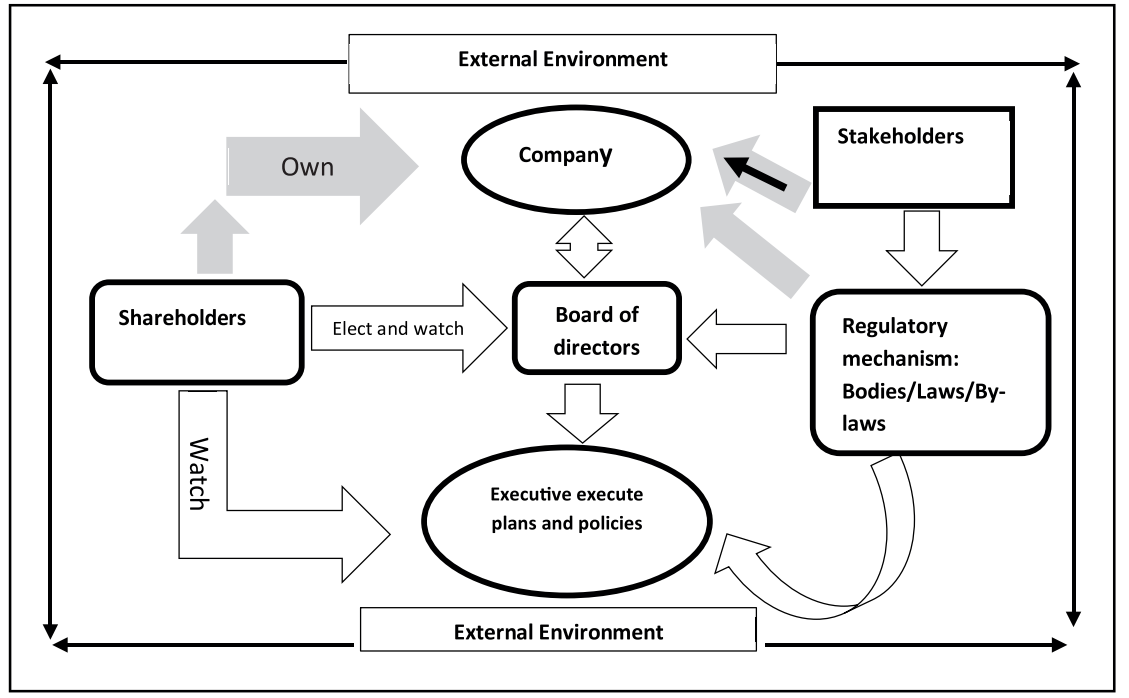

Source: Upadhyaya, T. P. (2013). Corporate governance practices in commercial banks of Nepal.

The above figure is corporate governance model of Nepal which describes that shareholders are the owner of the company. Shareholders representing both the group elect their 
representative to represent in the Board of Directors. The Board of Directors appoints and delegates their authority and power to executives/managers to run the company. The role of executives has also been watched from outside by the shareholders. The company is an artificial person and having lots of stakeholders. The regulatory authorities directly accountable to stakeholders regulate the company with the help of various acts, rules, and provisions.

Corporate governance model for the NetEnt Group: NetEnt seeks to apply strict standards and efficient processes so that its entire operations create long-term value for shareholders and other stakeholders. This requires maintaining an efficient organizational structure, internal control and risk management systems, and ensuring true and fair reporting and information. The governance of NetEnt is based on both external and internal regulations. NetEnt is subject to and complies with the rules of the Swedish Code of Corporate Governance (the code). There have been no material changes in corporate governance from the preceding year.

Figure 3: The corporate governance model of the NetEnt group

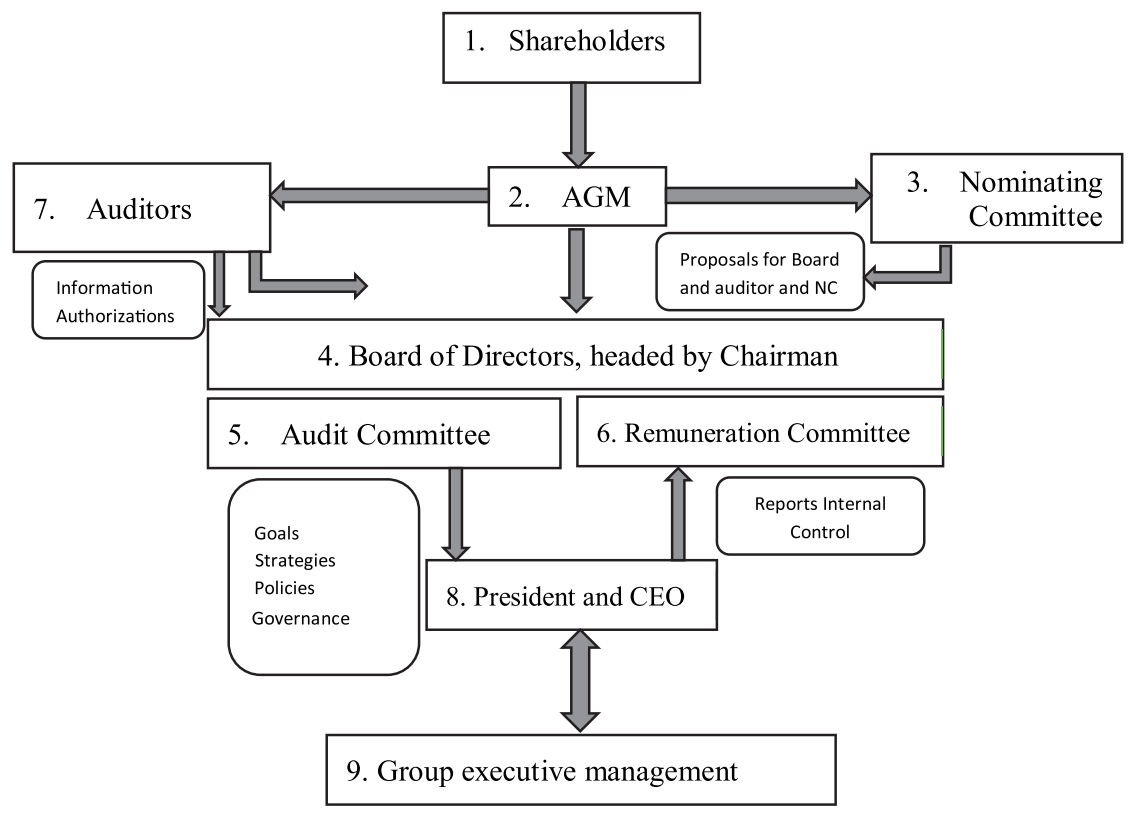

Source: NetEnt Corporate Governance Report (2016). Annual Report

The above figure is the model of the corporate governance of NetEnt group explain the structure and shows that the total number of shares divided between A shares and B shares, equal to a total of votes. One A-share grants entitlement to ten votes and one B-share grants entitlement to one vote when voting at a general shareholder meeting. The two share classes have equal rights to the company's assets and profit. At a general shareholder meeting, a shareholder may vote for the total number of shares represented and the Annual General Meeting (AGM) is NetEnt's highest governing body through which the shareholders exercise their influence in the company. The AGM decides on the procedures for appointment of 
the Nominating Committee. Similarly, The Board of Directors has overarching responsibility for NetEnt's organization and administration by establishing business goals and strategies, evaluating the executive management and securing systems for monitoring and control of established goals. The audit committee shall, without otherwise encroaching on the duties and responsibilities of the board of directors and main duty of the remuneration committee is to prepare matters relating to remuneration and other terms and conditions of employment for senior executives on behalf of the board of directors.

The Board of Directors has to prepared and adopted instructions regarding the CEO's duties and responsibilities, as well as obligations towards the board of directors. The CEO is responsible for managing and developing the company and running the ongoing administration of the company's affairs within the framework set out in the Swedish Companies Act, the company's strategic plan, the instructions for the CEO, and the guidelines and instructions provided by the board (NetEnt AB, 2018).

\section{Applications of transparency and accountability}

The subsequent sub-sections deal with applied reviews of transparency and accountability as powerful instruments for maintaining corporate governance.

\section{Transparency as an instrument for corporate governance}

Transparency is necessary for making the system of public service delivery effective; it enables information in the hands of the citizens in a manner that they may be able to claim their entitlements. In the context of Nepal the Nepalese banking industry, in recent years has practiced to disclose the material matters including regulatory requirements in line with the recommendations of the Basel Committee. Most of the banks have disclosed very few items of accounting standards compliance notes observed in their annual reports. However, commercial banks in Nepal, are now required to disclose profitability ratios like return on assets, earning per share which are important ratios to judge the performance and strengthening corporate governance of Banks (Guragain \& Adhikari, 2013).

Thus, in this way, transparency is essential tool to make all aware and the systems actually effective and more efficient by enabling information published and available to all. Johnston (2016) has said that transparency too rests on a partnership: officials must make information available, and there must be people and groups with reasons and opportunities to put information to use. Chief among those are an independent judiciary and a free, competitive, responsible press, but an active civil society is critical too. Rules and procedures must be open to scrutiny and comprehensible: a transparent government makes it clear what is being done, how and why actions take place, who is involved, and by what standards decisions are made. Then, it demonstrates that it has abided by those standards. Transparency requires significant resources, may slow down administrative procedures, and may offer more advantages to the well-organized and influential interests than to others. It also has necessary limits: legitimate issues of security and the privacy rights of citizens form two such boundaries. But without it, "good governance" has little meaning. 
Therefore, without transparency, it is little impossible to ensure good corporate governance in practice actually. So to make efficient and effective performances and practice of corporate governance, we should make information available, and there must be people and groups with reasons and opportunities to put information to use. Hence, in this way, it is an essential means of corporate governance practice.

\section{Accountability as a means of corporate governance}

Accountability is one of the major element of corporate governance in effective delivery of public services. The term accountability is linked to the idea of stewardship. The term could also be viewed as a summation of giving account of actions taken and being held answerable. And to give account would, by itself, be inadequate unless there is a means of holding the actor responsible (Adagbabiri, 2015).

Similarly, accountability is partly a matter of institutional design: formal checks and balances can and should be built into any constitutional architecture. But accountability requires political energy too: people, interest groups, civil society, the courts, the press, and opposition parties must insist that those who govern follow legitimate mandates and explain their actions. The same is true within governments: horizontal accountability (Schedler, Diamond \& Plattner, 1999; as cited in Johnston, 2016) depends upon the ability of one part of government to find out -- and, where necessary, to stop or correct -- what other sectors are doing. Those demanding accountability must be confident that they can do so safely, that officials will respond honestly, and that social needs and demands are taken seriously.

Since, it is a means of holding the actors responsible and also includes formal checks and balances that can and should be built into any constitutional architecture along with political energy too that help to confidentially and socially respond. Thus, accountability is a powerful and crucial means of corporate governance.

\section{Linking accountability, monitoring and evaluation}

There is no good governance without accountability which means, without the obligation on the part of public officials to report on the use of public resources and answerability for failing to meet stated performance objectives. There is no accountability without effective monitoring and evaluation either. Monitoring and evaluation can ensure the availability of information on interventions, resources utilized and outcomes. They can also facilitate efficient, effective and equitable usage of public resources; prevent waste, leakage and corruption; and hold political leadership and public servants accountable to the citizens that they are supposed to serve. Enhancing accountability in public service is often an incremental process. Specifically, accountability mechanisms and processes need to be strengthened in high risk areas prone to corruption such as public procurement, public works, concessions involving extractive industries, and privatizations, among others that involve large financial flows. Informal practices prone to corruption and the value system within a society are key areas to be analyzed (World Economic and Social Survey, 2014/2015). 


\section{Applications of corporate governance in emerging economies}

In developing countries with weak enforcement environments, the voluntary codes are the key to establishing good corporate governance (Rotinsulu, 2016). Effective implementation of voluntary codes in developing countries may contribute to stabilizing and improving economic growth as good corporate governance is recognized as essential for economic growth. The inadequate legal protections for minority shareholders, their inability to protect themselves and their vulnerability to political intervention is claimed to be common in developing civil law countries like Indonesia. To understanding regulatory systems in other developing economies with weak or corrupt formal legal systems. Developing countries with ineffective and corrupt formal legal and regulatory systems and low corporate governance performances seeking to improve legal certainty, justice and efficiency in order to advance national economic interests.

Rotinsulu (2016) believes that in creating nations with frail authorization situations, willful codes are the way to building up great corporate administration. The powerful execution of deliberate codes in creating nations may add to balancing out and improving monetary development as great corporate administration is perceived as basic for financial growth. The lacking lawful insurances for minority investors, their powerlessness to secure themselves and their weakness to political intercession is professed to be basic in creating common law nations like Indonesia. To understanding administrative frameworks in other creating economies with frail or degenerate formal legitimate frameworks. Creating nations with incapable and degenerate formal legitimate and administrative frameworks and low corporate administration exhibitions trying to improve lawful sureness, equity and productivity so as to propel national monetary interests. Formal laws and voluntary codes are "key to effective corporate governance in developing countries. In the context of formal law as did the justification that adopting legal ideas, concepts, processes and practices from developed economies may assist developing economies. A number of scholars suggested significant roles of the Code as informal law including a more effective and efficient regulatory instrument as well as an alternative regulatory strategy for developing countries with weak formal legal systems or weak law enforcement. In particular for developing countries, emphasized the integrity of formal law and associated institutions such as the courts and legal professions as significant factors rather than more general social and cultural issues. The developing countries like Nepal in developing economies, is also not an OECD member and has not been involved in establishing those principles to accommodate its conditions or interests.

The same author further claimed that formal laws and willful codes are critical to successful corporate administration in creating nations. With regards to formal law as did the avocation that receiving lawful thoughts, ideas, procedures and practices from created economies may help creating economies. Various researchers proposed huge jobs of the Code as casual law including an increasingly powerful and proficient administrative instrument just as an option administrative methodology for creating nations with feeble formal lawful frameworks or frail law authorization. Specifically for creating nations, accentuated the trustworthiness of formal law and related establishments, for example, the courts and legitimate callings as 
noteworthy factors instead of progressively broad social and social issues. The creating nations like Nepal in creating economies, is additionally not an OECD part and has not been engaged with setting up those standards to oblige its conditions or interests.

\section{Transparency and accountability in the Nepalese corporate sector}

Good governance means accountability in all its ramifications. It also means transparency, equity and honesty in public office. Indeed, effective democratic reforms of good governance rely on accountability and transparency (Adagbabiri, 2015). Upadhyaya (2013) has stated that transparency, accountability, information disclosures and stringent ethics practiced by companies are fundamental in winning investors' confidence. Capital market and so the corporate sector cannot develop with weak minority shareholders, inadequate or non-disclosures, violation of laws, non-compliance to the rules and regulations and lack of independent oversight of the directors. According to Sapkota (2008; as cited in Upadhyaya, 2013), disclosure system and transparency level of Nepalese financial institutions is not in well-built condition. The top-level, management is reluctant to disclose many friendly information, if disclose, that reduces the gap between management and the other stakeholders.

Dahal (2017) has said that the development of good governance in Nepal can be categorized into three different phases. The first phase of evolution of good governance covers the time period from 1951-1990, the second phase from 1990-2006 and the third phase from 2006-present day. The first major democratic movement in the history of modern Nepal is revolution of 1951. After this revolution, good governance started to evolve in Nepal. In the period from 1951-1990, public service commission was established; administrative reform commission was formed; civil service act and rule was drafted and implemented; and Supreme Court was established. The second major democratic movement in the history of modern Nepal is mass movement of 1990. After this mass movement some other series of events for good governance were held in the period from 1990-2006. During this period, higher public administrative reform commission under the chairmanship of Prime Minister Girija Prasad Koirala was formed; and local self-governance act 2055 was drafted. The third phase of development of good governance in Nepal took place after the democratic mass movement of 2006. During this period, good governance act and rule was drafted and new constitution was made. In this way, good governance gradually evolved in Nepal and it is still in the process of evolution. As a result of which there is improvement in the quality and quantity of services delivered to the people of Nepal.

Tamang and Malena (2011) have stated that Nepal's interim constitution guarantees various levels of citizen and civil society participation and establishes a number of institutions for public accountability and oversight. The 2007 Right to Information Act grants citizens broad access to public information and is very progressive compared to the rest of South Asia. The 2008 Good Governance Act stresses the need for a public administration that is "pro-people, accountable, transparent, inclusive and participatory". Elected local bodies of self-governance are acknowledged as essential to "ensuring peoples' participation in the country's governance" and the government's Three Year Interim Plan (2007/08 to 2009/10) 
specified decentralization as the key strategy for enhancing good governance and people's empowerment. The new 2010/11 to 2012/13 Three Year Interim Plan continues to emphasize good governance, inclusion, and balanced and decentralized development planned around probable federal governance structures. A range of constitutional and legal provisions are also in place to: regulate public financial management and to ensure oversight and accountability mechanisms for political parties and civil society organizations.

Thus, this way transparency and accountability are important means of corporate governance and it actually, this way practicing in our Nepalese corporate sectors to ensure good governance, which actually lacking.

\section{Exploration of related issues and challenges in the Nepalese context}

Issues and challenge for directors and executive management is to find outside directors who are sufficiently independent but still knowledgeable about and engaged in the business of the company on whose board they will sit. Independence reflects qualities of objectivity, experience, insight, and force of character. The need for directors to possess this blend of knowledge plus independence is critical, given the increased technical complexity of most business activities and the rapid pace of change in financial markets and practices. Another challenge in selecting outside directors is how to balance general business knowledge with specific industry knowledge and technical expertise in areas such as accounting, finance, and labor markets. Finding such outside directors can involve a tough balancing act and its very difficulty of finding qualified directors who have the time to devote to the affairs of the company and who are willing to face the risk of shareholder lawsuits. The risk is that as outside directors' compensation increases, their independence may wane and, instead of functioning as watchdogs for shareholders, they may increasingly function as lapdogs for management. Getting the right balance of expertise and independence so that the board does not rubber-stamp the decisions of top management is a major challenge (Maradi \& Dasar, 2014). It consists the followings as mentioned:

a. Unsophisticated equity market vulnerable to manipulation and with rudimentary, traditional analyst activity.

b. Dominations and monopoly of family firms.

c. High level of corruption, become visible only after a revelation of big financial scam.

d. Weak and non-transparent monitoring system.

e. Lack of respect for shareholders and low financial disclosure.

f. Lack of appropriate leadership

After a decade long civil war, Nepal entered into a phase of political as well as social transition since 2006 with the 12 point understanding between the political parties and then rebel CPN-Maoist. With elongating transition in the country, none of the governments which were formed after 2006 are not yet able to provide a sense of good governance towards the general public of Nepal (Pandey, 2015). 
The major challenges faced by the governing bodies during this time and further on are described as under.

a. Survival oriented nature of the cabinet: Nepal has always suffered by the survival oriented nature of the cabinet. Since, the first election of constituent assembly in 2008, no political party has been able to garner a majority votes to establish a single party cabinet. So, all the cabinets which were installed after 2008 were and are joint cabinets of the political parties. The difference between the political ideologies and mistrust between the parties taking part in government are seen polarized with other forces and operating to make a new coalition government. So, every cabinet thrived for survival. So to sustain, the government has always been trying to convince and work in the benefit of parties in volition rather than focusing on meeting the demands of the people. This has resulted in numerous unpopular decision-making from the cabinet and failure in drafting the constitution of Nepal which is a major task to be completed to end the phase of transition. The consequences are eroded accountability, transparency and legitimacy of the government as well as the political parties.

b. Corruption: Corruption in government bodies and other public sectors have hampered the quality of governance of the country. The level of corruption is so critical that Nepal has been listed in the most corrupt countries of the world. According to Transparency International report, Nepal ranks 116 position of least corrupt countries out of 177. The transparency is highly questioned when the public servants are corrupt. In addition to this, corruption not only hampers in the development process of the country and hampers in developing the public goods but it becomes more critical when corruption becomes a culture and starts to get accepted in the society. Then, people themselves are willing to bribe the officers to get their work done. When it becomes two way then everyone are encouraged to become corrupt.

c. Institutionalized problems: Apart from corruption, nepotism, irresponsibility etc. have become institutionalized problems of Nepalese bureaucracy. Handing over the better jobs to their keens, delaying the jobs of general public are simple examples. These problems have long ago been institutionalized in Nepalese bureaucracy and it has now become a bureaucratic culture. This has hampered the transparency, responsiveness and accountability of the government.

d. Socio-economic and political disparities: Nepal is a country where more than $25 \%$ of its population live under the line of poverty. They live in less than a dollar a day. In addition to this the social structures of the country are so discriminating which have always hindered the equal participation of marginalized groups in the decision making process and receiving services provided by the state. To worsen this, the political instability has always played a important role to plant fear in people's mind. The political stalemate and deadlocks compels people to be pessimistic about the betterment of the society in any time. This has resulted in brain drain, immigration, huge demographic changes and flow of working forces to for- 
eign countries in order to guarantee their survival in future.

e. Ethnic disharmony: In the recent period, the ethnic tensions between the people of Nepal has highly increased. The revival of historical trauma has caused antagonistic relations between different ethnic groups creating security and social problems. This has increased mistrust between the ethnic groups and sometimes they even come to the phase of encounter. Good governance is not possible without peace, without harmonious relationship between the citizens of the state. The ethnic tensions rising in the lower lands and eastern hills has increased more pressure on the security sector.

f. Weaker state capacity: Nepal is a poor, militarily weak and socially fragile nation. The elongation of transition period in the country has worsened this condition. Therefore, it is obvious that the state capacity of the country is weak. Even if the government wills to make any reforms it does not have enough resources. It is very difficult to maintain social and legal order in such a country to any kinds of government because the government is not able even to provide basic services it should be providing without the help of donors and international community. But when assistance is seemed from others, it always comes with some sort of interference which may be political, social or economic. So it is very difficult to any government to maintain a balance between these all aspects and ensure good governance.

Thus, these are the various issues and challenges facing the implementation of transparency and accountability in the Nepalese corporate sectors which must be analyzed and addressed carefully and efficiently for smooth, reliable, effective and efficient functioning to ensure better and greater performance and output of Nepalese corporate sectors.

\section{Method of study}

This paper is the outcome of two consecutive articleship projects undertaken as academic course requirements in Corporate Governance for the partial fulfillment of Master of Business Administration (MBA) degree at Quest International College, an affiliate institution of Pokhara University, Faculty of Management. Both the articleship projects were accomplished taking a working duration of three months each by present researchers in the spring season of 2019.

The present work was accomplished using a fully qualitative method of inquiry by performing a critical review and analyses of information related to the status of compliance of transparency and accountability in the Nepalese corporate sector.

The present researchers used a thematically guided approach of inquiry to maintain effective control of the diversity and intensity over the coverage of subject matter of inquiry. Keeping in view the objective of the study and nature of research questions taken into consideration, adequate effort was vested on exploration and critical analyses of information collected from diverse sources, mostly using desk research method.

Thus, all the findings of this work are based on secondary information analyses. Information has been collected and shifted from the documents such as textbooks, journals, 
official declarations, group discussions, seminar sessions, newspaper articles and course facilitator expert opinion.

\section{Discussion and findings}

In a federalized society, every institution are expected to be more accountable and transparent in every sector. However, the trend revealed by the study is exactly the other way around in the context of Nepal for various reasons. The cases of poor governance and the case studies were deliberately chosen involving both public and private equities to identify the best corporate governance practice that can be adopted elsewhere. Depicted from class proceedings: Since, Nepal has gone into federalized structure, it is also important to federalize the corporate sector, organization structure, and market coverage. It has two reasons; first it is to empower the local government and second is to bring the local government into the decision making unit, having autonomous boards, giving equal opportunities. For instance, the development of upper Tamakoshi is based in local ownership. With the view of federalization, various acts are required to be deregulated in order to influence more FDIs. For example, the globalization-receptive leadership from government campaigned the investment summit and amended the new acts related to FITTA.

Essence of effective transparency: Every stakeholders including the crucial governing body and leadership of an organization is responsible for the direction of good transparency in the organization. Transparency is underpinned by good governance, which in turn leads to good management, good performance, good stewardship of public interest, good public engagement and, ultimately the good outcomes. Without trust and confidence, the company may collapse in the long term. Transparency enables accountability by providing reliable, relevant and timely information about the organization's activities to the authority or public.

Essence of effective accountability: Accountability processes will become more efficient when records are managed effectively and systematically because the evidence can be made available within a reasonable response time and decision making will be more efficient. For instance, good record keeping can be implemented in the board without much cost and over-engineering because the basic infrastructure is already there. Administration staff are provided with shared drives that are meant for sharing of documents and records. It is essential for financial institutions to demonstrate a high level of transparency and accountability, particularly in an era where corporate crime and terrorism is deemed as a threat to the global economic stability and safety.

Goals of effective governance: Thus, corporate governance mechanism tries to reduce the problems between the principal-agent. The principal delegates the decisive rights to the manager to act in the mechanism is implemented to assist in aligning the functions of managers with shareholders. The hazard, is the great administration that can turn into a one-measure fits-all trendy expression lacking explicit importance. The rundown of explicit objectives for administration is the one that won't fulfill all natives and authorities all over the place, yet that reminds the issues recognized up until now, and of the advantages that can be accomplished are: 

a. Legitimate, viable, responsive organizations and strategies
b. Understandable procedures and results
c. Incentives to continue great administration
d. Vertical responsibility
e. Horizontal responsibility and pioneers, and among fragments of government.

Similarly, there are multiple outcomes of corporate governance (depicted from the class proceedings of Rijal, C. P., March 24, 2019) which are:

a. It ensures the transparent, effective system compliance, discipline and regulation based on increased level of transparency and accountability.

b. It increases the organizational productivity and performance in the long term.

c. It develops a corporate branding in the market and of economy as well, which will attract the foreign direct investment, multinational companies and reduces the divestment.

d. It ensures the rational public participation and empowerment based on the intensity of needs of people.

e. It improves the overall process, climate, and maintains the quality-of-work life in organization.

f. It transforms the global competitiveness of local market, resources and industries as well.

The success of firms depends on their corporate governance and financial performance. The existing literature opines that except banking and financial sectors of Nepal, various companies have failed due to lack of proper transparency and accountability towards public. However, studies suggest that corporate governance is essential for both private and public sectors to make decision of governing and empowering Nepalese corporate sectors. These issues are burning in the context of Nepalese corporate sectors where organizations have been involved in various unethical practices. These issues have emerged as key ways to address both the developmental failures and democratic deficits. Similarly, various reformation policies along with better resource allocation needs to be made based on OECD principles, BASEL framework for banks, and various other international practices in order to deal with such issues and bring empowerment in Nepalese corporate sectors.

Transparency discloses information to the users which are important to analyze the performance and strengthen the organization's corporate governance. For this, rules and procedures needs to be open and comprehensive. Without transparency, it is complex to ensure good governance. Similarly, accountability ensures effective delivery of public services. It is the act of giving account of actions taken and being held answerable. Those demanding accountability should be confident about honesty. In emerging nations where formal legitimate frameworks are lacking, it is emphasized that integrity of formal law and associated institutions are the significant actors and Nepal is involved in establishing those guidelines to accommodate the similar interests. Thus, this way transparency and accountability are important means of corporate governance and it actually, this way practicing in our Nepalese corporate sectors to ensure good governance, which actually lacking. 
The Board of Directors (BODs) are important to practice the corporate governance if any firms and consider the importance of the independent directors of board, after the NRB has made mandate regarding the appointment of independent director. Thus, this means of corporate governance mechanism tries to reduce or eliminate the problems between the principal-agent. The practices of great administration can turn into a one-measure fits-all trendy expression lacking explicit importance, making it visible.

Therefore, these are the various highlights that was found in this study which actually directly and indirectly affect the Nepalese corporate sectors. So it must be analyzed deeply and correctives measures should be made accordingly and implemented effectively for the smoothness in functioning of corporate sectors and thus to enhanced, improved and empowered these sectors in our country, Nepal.

\section{Conclusions}

The study has focused on analyzing the major element of corporate governance, i.e., transparency and accountability in the present context of Nepalese corporate sector. Basically, this study has been based on review of literature from different perspectives at different times. As a result, it has not incorporated any kind of quantitative analyses.

After reviewing and analyzing different resources including journal articles, books, research based publications, policy documents and other similar resources, we could firmly realize that in this modern, more competitive and globalized business age, economic activities are growing up with perfection of governance and functional operation. From this learning, we could claim that the success of an institution depends on its effectiveness in governance and financial performance.

Based on exploratory analyses of the information gathered during this work, it can be inferred that the issue of public accountability and transparency in Nepal remains weak. On the other hand, this study found that except banking and financial sector of Nepal, many companies have failed due to lack of adequate compliance of transparency and accountability towards the stakeholders and general public.

The banking and financial institutions are able to perform comparatively better in Nepal partly because of Nepal Rastra Bank's robustness in monitoring, supervision and policy guidance as well as its strictness in maintaining compulsion of financial disclosure (transparency). Through this discourse, we could also identify that still the BFIs could not produce results up to their full potential due to promoters and directors vested financial interests and inferior corporate governance.

Corporate governance reforms are of great significance for developing countries like Nepal to gain a sustained effort to attract foreign direct investment (FDI), foreign portfolio management (FPM), and to mobilize savings through capital markets. However, significant efforts are made to address the issue of corruption, Nepal still needs to work very seriously to address this issue. Therefore, there should be zero tolerance against all cases of corruption. 


\section{Suggestions for policy implications}

Corporate Governance has been a newly debated topic in the corporate world of Nepal. Along with the corporate governance, compliance for transparency and accountability has become a major issue. After analyzing several studies and policy documents, the following suggestions shall be noteworthy to improve the Nepalese corporate sector:

a. In coordination with local and provincial governments, the federal government of Nepal should create a legal provision to all private and public sector enterprises for the mandatory disclosure of their financial information in a quarterly as well as annual basis.

b. BAFIA needs to be amended to address the policy urgency to transform institutional structure, design and services with respect to the spirit of federal structural system under changing national scenario.

c. The decision making institutions need to prioritize the organizational data that are relevant for employees, customers or other stakeholders to encourage them to take part in company accountability efforts.

d. Companies should create a range of avenues (both online and offline) for citizens to get access to their information by making it visible and retrievable.

e. The companies should have the special departments to handle each request for information coming into the company so that other interested parties seeking information can be served well.

f. The management should train managerial committees, employees and selected community groups regarding the usage of data based on demand accountability.

g. Economic disparities and social inequalities are taken as the main cause of decade long civil war. So, all the tiers of government should focus on the development works, economic programs and should encourage awareness programs to overcome social stereotypes, stigmas and superstitions. While doing so, the religious, ethnic and cultural aspects should be taken in high consideration.

h. Policy makers need to revise regulation for promoting social awareness through more mandated public disclosure of information.

i. Top-management need to develop more responsive work-conditions and provisions to promote transparency and accountability in the organizations.

Thus, in a nutshell, in order to assure good governance in a country with weak state capacity like Nepal, it needs a strong political will to make social political and economic reforms. So, the government should focus on the development works, economic programs and should encourage awareness programs to overcome social stereotypes, stigmas and superstitions. While doing so, the religious, ethnic and cultural aspects should be taken in high consideration. Corporate governance has been proving a very efficient and effective system for our economy and to save the interest of shareholders but some more efficient monitoring 
and transparent internal audit system, efficient board and management can lead it to effective corporate governance through transparency and accountability in Nepalese corporate sectors. Focus on corporate governance should be broaden to encourage emerging market companies to bolster strategic management of sustainability issues and enhance public disclosure on sustainability performance.

All the tiers of government and other regulatory bodies in Nepal must concretely respond by designing and strengthening institutional system and structures for safeguarding public integrity, increase access to information and foster transparency and accountability.

\section{References}

Adagbabiri, M. (2015). Accountability and transparency: an ideal configuration for good governance. Developing Country Studies, 5(21), 2. Available at: https://www.iiste.org/Journals/index.php/ DCS/article/viewFile/27454/28168. Retrieved on: December 28, 2018.

Adhikari, P. (2014). Corporate governance practices in commercial banks in Nepal. Journal of Research in Management \& Technology, 3(9), 56. Available at: https://abhinavjournal.com/journal/index. php/ISSN-2320-0073/article/viewFile/416/pdf_109. Retrieved on: January 3, 2019.

Armstrong, E. (2005). Integrity, transparency and accountability in public administration: recent trends, regional and international developments and emerging issues. United Nations, Department of Economic and Social Affairs, 1-10. Available at: http://unpan1.un.org/intradoc/groups/public/ documents/UN/UNPANo20955.pdf. Retrieved on: May 7, 2019.

Ashour, A. S. (2004). Integrity, transparency and accountability in public sector human resources management. Transparency and Accountability in the Public Sector in the Arab Region, p. 2. Available at: http://unpan1.un.org/intradoc/groups/public/documents/un/unpan01539o.pdf. Retrieved on: January 3, 2019.

Avellaneda, S. D. (2006). Good governance, institutions and economic development: Beyond the conventional wisdom. The Forum de Recerca, Departament de Ciencies Politiques Socials, p. 7. Available at: https://pdfs.semanticscholar.org/o15e/6fb2c82f98a6oce93b6ed1abco74cd972dao.pdf. Retrieved on: January 3, 2019.

Berle, A. \& G. Means (1932). The Modern Corporation and private property. Open Journal of Business and Management 3(2). MacMillan, New York. Available at: http://www.scirp.org/(S(lz5mqp453edsnp55rrgjct55))/reference/ReferencesPapers.aspx?ReferenceID=1460233. Retrieved at: May 9, 2019.

Claessens, S., \& Fan, J. P. (2002). Corporate governance in Asia: A survey. International Review of finance, 3(2), 71-103. Available at: http://www.cuhk.edu.hk/ief/josephfan/doc/research_published_paper/o6.pdf. Retrieved on: April 25, 2019.

Dahal, G. (2017). Corporate Governance in Asia: A Survey. International Review of Finance, 3(2), 71-1o3. Available at: https://www.researchgate.net/publication/4762002_Corporate_Governance_ in_Asia_A_Survey. Retrieved on: April 26, 2019.

Gaventa, J., \& McGee, R. (2013). The impact of transparency and accountability initiatives. Development Policy Review, p. 2. Available at: https://onlinelibrary.wiley.com/doi/epdf/10.1111/dpr.12017. Retrieved on: january 12, 2019.

Ghimire, R., Acharya, R., Shrestha, R., Singh, R., \& Bhattarai, R. (xxxx). Corporate Governance CG. Nepalese Journal of Corporate Governance, 103. Available at: http://library.uniglobe.edu.np/opac_ css/doc_num.php?explnum_id=5. Retrieved on: April 25, 2019. 
Gisselquist, R. M. (2012). Good governance as a concept, and why this matters for development policy (No. 2012/30). WIDER Working Paper. Available at: https://www.researchgate.net/publication/23981090o_Good_Governance_as_a_Concept_and_Why_This_Matters_for_Development_Policy. Retrieved on: January 4, 2019.

Guragain, M. K., \& Adhikari, P. (2013). Nepal on the path of IFRS implementation. Journal of the Institute of Chartered Accountants of Nepal, 16(1), p. 7-10. Available at: https://drive.google.com/ file/d/oByLVm4xoCgu1 YUhFU3JhcWM4Szg/view. Retrieved on: January 5, 2019.

Hale, T. N., (2008). Transparency, accountability, and global governance. Global Governance, 14, 73-94. Lynne Reiner Publishers. Available at: http://www.jstor.org/stable/27800692. Retrieved at: March 30, 2019.

Johnston, M. (2006). Good governance: Rule of law, transparency, and accountability. United Nations Public Administration Network. Available at: http://unpan1.un.org/intradoc/groups/public/documents/un/unpan010193.pdf. Retrieved on: May 7, 2019.

Kalika, S. N. (2018). An introduction of corporate governance. Kathmandu: Employees Provident Fund. Available at: https://www.epfnepal.com.np/downloads/articles/Satya_Kalika Narayan.pdf. Retrieved on: January 10, 2019.

Khodary, Y. (2016). Good governance: a new perspective for institutional reform . International Journal of Public Policy, Vol 12. pp. 362-363. Available at: https://www.researchgate.net/publication/309165408_Good_governance_A_new_perspective_for_institutional_reform_A_comparative_view_of_water_education_and_health_institutions_in_Egypt. Retrieved on: January 4, 2019.

Kutcher, E.J., Bragger, J.D., Srednicki, O.R., \& Masco, J.L. (2010). The role of religiosity in stress, job attitudes, and organizational citizenship behavior. Journal of Business Ethics, 95, 319-337. Available at: https://psycnet.apa.org/record/2010-16065-010. Retrieved on: January 3, 2019.

Leal Filho, W., Brandli, L., Moora, H., Kruopienė, J., \& Stenmarck, Å. (2016). Benchmarking approaches and methods in the field of urban waste management. Journal of Cleaner Production, 112, 43774386. Available at: https://www.sciencedirect.com/science/article/pii/So959652615012925. Retrieved on: May 7, 2019.

Levy, D., Brown, H. S., \& Jong, \&. M. (2010). The contested politics of corporate governance: the case of the global reporting initiative. Business and Society, p. 5-6. Available at: file://D:/CG/project/ LevyBrownDeJong2009GRIproofs.pdf. Retrieved on: January 13, 2019.

Magar, G. T., Bohara, J., Thapa, K., Chapagain, K. P., \& Sah, K. K. (xxxx). Testing the relationship between corporate governance and bank performance: an empirical study on Nepalese Commercial Banks. Nepalese Journal of Corporate Governance, 1(2), 68-77. Available at: http://library. uniglobe.edu.np/opac_css/doc_num.php?explnum_id=5. Retrieved on: March 13, 2019.

Manandhar, N. (2016, February 24). Business ethics: most popular course. Daily Newspaper. Available at: https://thehimalayantimes.com/opinion/business-ethics-popular-course/. Retrieved on: January 5, 2019.

Maradi, M., \& Dasar, P. (2014). An analysis of corporate governance issues in the indian context: Challenges and prospects. International Journal of Management Research, 2(3). Available at: https:// www.researchgate.net/publication/324173671_ An_Analysis_of_Corporate_Governance_Issues_in_the_Indian_context_Challenges_and_prospects. Retrieved on: January 5, 2019.

McGee, J. G. (2011). The impact of transparency and accountability initiatives. p. 1. Available at: https:// www.shareweb.ch/site/DDLGN/Documents/John\%20Gaven ta\%20Rosie\%20McGeeThe\%20 
Impact\%20of\%20Transparency\%20and\%20Accountability\%20Initiatives.pdf. Retrieved on: January 5, 2019.

Nepal Rastra Bank (2013, April). Bank supervision report. Bank Supervision Department, Kathmandu: Author. Available at: https://www.nrb.org.np/bsd/reports/Annual_ReportsAnnual_Bank_Supervision_Report_2001-2002.pdf. Retrieved on: April 25, 2019.

Organization for Economic Corporation and Development. (1999). OECD principles of corporate governance. Paris, France: Organization for Economic Co-operation and Development. Available at: https://books.google.com.np/books/about/OECD_Principles_of_Corporate_Governance.ht$\mathrm{ml}$ ?id=Uv_RZsR5dIC\&printsec $=$ frontcover\&source $=\mathrm{kp} \_$read_button\&redir_esc $=\mathrm{y} \# \mathrm{v}=\mathrm{onep}-$ age\&q\&f=false. Retrieved on: January 10, 2019.

Organization for Economic Corporation and Development. (2015). G20/OECD principles of corporate governance. Ankara: Organization for Economic Co-operation and Development. Available at: https://www.oecd.org/daf/ca/Corporate-Governance-Principles-ENG.pdf. Retrieved on: January 16, 2019.

Pandey, B. (2015, December 8). Challenges of good governance in Nepal. Eastern Initiative for Social Science Research. Available at: http://eissr.blogspot.com/2015/12/challenges-of-good-governance-in-nepal.html. Retrieved on: January 2, 2019.

Sapkota, A. K., Gyawali, A., Thapa, A., Guvaju, A., \& Panthee, A. (2015). Corporate governance and bank efficiency: a case of Nepal. Nepalese Journal of Corporate Governance, 1(2), 10-22. Available at: http://library.uniglobe.edu.np/opac_css/doc_num.php?explnum_id=5. Retrieved on: March 12, 2019.

Sen, P. K., \& Garani, A. P (2015). Does corporate governance (cg) reform necessarily enhance firm performance? Recent evidence from India. Nepalese Journal of Corporate Governance, 1(2), 93. Available at: http://library.uniglobe.edu.np/opac_css/doc_num.php?explnum_id=5. Retrieved on: April 25, 2019.

Tamang, S., \& Malena, C. (2011). The political economy of social accoutability in Nepal. Program for accoutability in Nepal, 6. Available at: http://siteresources.worldbank.org/NEPALEXTN/Resources/2235541296055463708/PoliticalEconomy.pdf. Retrieved on: January 2, 2019.

Times Reporter. (2018, December 30). Stakeholders stress corporate governance. Kathmandu: The Himalayan Times. Available at: https://thehimalayantimes.com/business/stakeholders-stress-corporate-governance/. Retrieved on: May 6: 2019.

Turkish Industry and Business Association. (TÜSİAD). (2005). Sermaye piyasaları için ornek sirket yapısı (Company structure for capital markets). Available at: http://www.uidergisi.com.tr/wp content/ uploads/2011/o6/Kuresellesme-ve-Turk-Isadamlari-Dernegi-TUSIAD-Ornegi.pdf. Retrieved on: May 7, 2019.

Upadhyaya, T. P. (2013). Corporate governance practices in commercial banks of Nepal. An unpublished doctoral dissertation report, Banaras Hindu University, Varanasi. Available at: http://202.45.147.21:8080/jspui/bitstream/123456789/295/1/70. Dr.Tara\%20Prasad\%20 Upadhyay.pdf. Retrieved on: January 2, 2019.

Wolman, H., Levy, A., \& Hincapie, D. (2008). Economic competitiveness and the determinants of sub-national area economic activity, 2-11. Available at: https://gwipp.gwu.edu/sites/g/files/zaxdzs2181/f/ downloads/Working_Paper_o44_Governance.pdf. Retrieved on: January 2, 2019. 